\title{
The impact of Non-Tariff Measures (NTMs) on Moroccan foreign trade: Comparison between developed and developing countries
}

\author{
Mustapha Khouilid ${ }^{1}$, Abdellah Echaoui ${ }^{2}$ \\ ${ }^{1}$ Researcher in International economics, Department of Economics, Mohammed V University in Rabat, Morocco \\ ${ }^{2}$ Researcher in Economics, Department of Economics, Mohammed V University in Rabat, Morocco
}

\begin{abstract}
The world economy is still far from the ideal model of a barrier-free market, freed from any barriers to trade. In this paper, we will try to analyse the impact of non-tariff measures on Moroccan exportations. The review of the literature shows that the effect of non-tariff measures on international trade exceeds the tariff ones. In order to analyse empirically the impact of non-tariff measures on Moroccan foreign trade, we used the elasticity of imported demand and an estimated gravitational equation for a sample of 28 countries of different levels of development. Our database consists of 4242 tariff lines during the period 2000-2015. The results show that non-tariff measures negatively affect Moroccan foreign trade. Exporting sectors are not affected to the same degree and suffer more in trade with economically similar countries (Developing countries) than in trade with developed nations.
\end{abstract}

Keywords: Ad-valorem tariff equivalents, Gravity equation, International trade, Non-tariff measures.

\section{Introduction}

Moroccan trade policy has been based in recent years on the conclusion of several free trade agreements with various trading partners. This change in the trade policy structure of Morocco and other states is influenced by an international trade liberalization movement advocated by the WTO, which states that economic growth is conditioned by the free trade. On the other hand, the results of the conclusion of agreements do not correspond to the expectations of Moroccan exporting and importing companies. The conclusion is that international trade liberalization has only affected tariffs, giving rise to new forms of protectionism based essentially on trade-restrictive non-tariff measures (NTMs). Non-tariff measures have become the heart of state trade policies, which gives them leeway to be able to act on the volume of imports and exports especially for sensitive products. Moroccan companies are suffering more and more from this type of obstacle disguised under the banner of the protection of human health, animal health and the protection of the environment.

According to the WTO, non-tariff measures, such as technical standards and health standards, should not be used for any purpose other than their legitimate objective, namely protection of human and animal life and protection of the environment. The report [1] emphasizes the importance of non-tariff measures (NTMs) as real challenges to trade liberalization, focusing on countries that suffer most from such measures, Morocco is included in the list of these countries. Indeed, in a context where protectionism takes on new disguised forms, what is the impact of Non-Tariff Measures on Moroccan exports?

Are the NTMs in Morocco-Developed Countries more restrictive than those applied in MoroccoDeveloping countries trade? In order to answer these questions, it is assumed that Moroccan exports would suffer from restrictive NTMs applied by Morocco's trading partners, limiting the volume of exports differently according to sectors (H1). Developed countries benefit from technological advances in imposing non-tariff measures. Then, Morocco-developed countries trade would suffer from NTMs more restrictive than those applied in Morocco-Developing countries trade (H2).

This paper aims toanswer these questions, first proposing a review of the literature on non-tariff measures, before moving to an econometric study on the case of Morocco. The aim here is to simulate, using a gravity model and the elasticity of imported demand, the effect of the removal of non-tariff measures on Moroccan exports. A final section is devoted to discuss the results and to formulate a conclusions for the study.

\section{Literature Review on Non-Tariff Measures}

\subsection{Identification of non-tariff measures: a complex task}

The global economy is still far from the ideal model of a barrier-free market, free from trade barriers. This is the message of the Doha Development program [2]. Tariff barriers erected at the borders and within countries have been reduced considerably in the course of successive trade negotiations following GATT and WTO rules. At the same time, there is an increase in the relative importance of non-tariff measures, both as an instrument of protection and as a means of regulating trade.

The NTMs may include policies that restrict or prevent imports, impose variable levies, surcharges or discriminatory taxes on imports, which require pre-import deposits, which subsidize production and exports, or 
which restrict imports exports. In his work, [3] adds a normative dimension to define non-tariff measures as "any measure that causes a distribution of goods and services exchanged at the international level in such a way as to potentially reduce real income". This definition does not imply a judgment on the actual economic effect of non-tariff measures or their effectiveness in achieving different policy objectives. It does not imply legal status under the WTO or other trade agreements.

Another definition has been attributed to non-tariff measures. The NTMs are presented as any trade distorting measure, but is not a tariff where a distortion exists when the domestic price differs from the price at the border. These include export restrictions and export subsidies [4]. The WTO, for its part, distinguishes nontariff measures based on a legitimate objective (such as the protection of human health), which can be introduced in a WTO-compatible manner, discriminatory purposes, which are put in place as a means of disguised protectionism. The report on world trade points out that non-tariff measures encompass all measures affecting trade other than tariffs. But since most regulatory measures taken by governments can, at least in principle, have an impact on trade, the scope of NTMs is wide and its boundaries are unclear [5].

According to [6], legitimate barriers provide more information about the traded good and improve its characteristics, which can stimulate demand and increase trade. Thus, [7] states that NTMs can have a positive impact if they are harmonized because harmonization leads to a reduction in production costs through economies of scale. However, [8] explains that in the case of protection of an emerging industry, an import quota (one of the forms of quantitative measures) is preferable to a subsidy. Support for the nascent industry is expected to decline as learning takes place.

So we see that there is no formal definition of non-tariff measures. According to [9], there are all sorts of non-tariff measures. Some are directly related to trade (import quotas, import surcharges, anti-dumping measures), Others are related to trade to the extent that their implementation is controlled at the border (Standards on labelling and packaging, health standards), while a third group of barriers arises from policy decisions (public procurement, investment restrictions, protection of Intellectual property rights).

The definition of what NTMs easily highlights their great diversity. International organizations and institutions have for some years taken the problem into account by trying to establish a precise and valid nomenclature for each type of non-tariff barrier. It should be noted that, in most cases, it is not the measure in itself that is a barrier to trade, but rather its implementation.

The difficulty to address is the identification of NTMs and to analyse their nature and scope is related to the fact that they can take different forms and correspond to different objectives. Objectives vary by country and product. Moreover, compared to tariffs, for which quantitative databases exist to measure levels of protection, the identification of non-tariff measures and the assessment of their impacts encounter considerable difficulties in terms of the lack of data and the complexity of their evaluation methods.

It is not always easy to identify or define non-tariff measures, or to be certain of their purpose. These have effects on prices, quantities or on the social welfare of the importing country as well as of the exporting country. They can be a major obstacle for both exporters trying to access foreign markets for importers who have to comply with a wide range of domestic market requirements. It is essential to distinguish between NTMs protections aimed at eliminating the asymmetry of information and supplies all information necessary for the protection of consumer health and safety and protectionist NTMs aimed at protecting domestic and Limiting foreign competition.

\subsection{Non-tariff measures more restrictive than tariffs}

A number of studies have attempted to quantify the effect of non-tariff measures on international trade. The objective is to estimate the extent to which these barriers contribute to the overall level of trade restrictiveness. This can help advance the negotiating process. Indeed, NTM quantification begins with a thorough knowledge of these barriers and leads to assessments of the impact of the measures on trade and economic prosperity. Nevertheless, there is no consensus on how to measure and quantify non-tariff measures.

In their work, [10] use a sample of 91 countries to assess the impact of non-tariff measures on trade in each of 4575 6-digit Harmonized System (HS) classification of goods. The authors indicate that for $55 \%$ of the tariff lines affected by non-tariff measures, the ad-valorem tariff equivalent of these measures is larger than the tariff. At the level of the global trade restrictiveness index, the authors note a degree of restriction which is twice as high as that of customs duties. For their part, [11] use two indices of trade restrictiveness, a tariff restrictiveness index rated "IRTD" and an overall index of restrictiveness (tariff and non-tariff measures) noted as "IGRE". The results of their study show that a $10 \%$ reduction in the IRTD increases trade flows by $2 \%$, while the elimination of non-tariff measures at the same percentage increases trade by $3.8 \%$, is $1.8 \%$ more. This result reflects the importance of the degree of trade restrictiveness of non-tariff measures that exceeds tariffs.

In its latest report on world trade, the WTO confirms that the trade restrictiveness associated with nontariff measures is much higher than tariff-related trade. More precisely, it measures the contribution of non-tariff measures twice as high as that of tariffs [12]. For example, [13] report that tariffs have reduced trade by 5\%, 
while non-tariff measures have decreased by about 7\%. In the same context, [14] find a negative correlation between tariffs and per capita income, while NTMs increase with GDP per capita. This may mean that the more a country develops and grows, the more the level of restriction related to non-tariff measures increases relative to tariffs.

In its report on non-tariff measures, [15] considers rules of origin as a very restrictive trade policy instrument, equivalent on average to a $4 \%$ tariff.The NTMs appear to have a significant impact on trade in a way that is more important than tariffs because these measures have always been considered substitutes for tariffs. As a result, traditional trade agreements contain provisions to address the problem of tariff replacement by nontariff measures. Accordingly, [16] states that non-tariff measures significantly limit market access more than tariffs. The report emphasizes that although the preference systems grant to low-income countries with relatively low tariffs especially for agricultural exports. Once taken the ad-valorem tariff equivalent of non-tariff measures, the total restrictiveness (rates Customs and NCD) climbed to almost 27\%.

A study by [17] aims to evaluate the effect of technical regulations on imports of 690 agricultural products. The two forms of non-tariff measures (Sanitary and Phytosanitary Measures and Technical barriers to trade) do not have a bilateral dimension because they are applied unilaterally by importing countries and applied to all exporting countries. Based on estimates by gravity model [18] confirm that the Sanitary and phytosanitary measures and Technical barrier to trade standards significantly reduce bilateral imports. When assigning exporting countries into three groups (OECD, Developing Countries and least developed countries "LDC"), they find that the exports of the OECD countries are more affected by rates than developing countries or LDCs.

Standards other than SPS / TBT measures may have a negative impact on trade and international exchange. By examining the impact of non-tariff measures on export development, [19] obtained a 9\% reduction in exports as a result of testing procedures and a $3 \%$ following inspection procedures. The cumbersomeness of these procedures slows down trade significantly. Thus, [20] estimate that a one-day export delay means a trade reduction of at least $1 \%$ and $7 \%$ in the case of agricultural exports.

Whatever their objective, non-tariff measures entail costs related to compliance and conformity assessment, which particularly affect developing countries such as Morocco, which do not have the means to establish effective regulations Standards, and compliance procedures. The following paragraph presents the methodology used for the empirical study to measure the impact of non-tariff measures on Moroccan exports.

\subsection{Construction of the measurement model}

\section{The conceptual and methodological framework}

To study empirically the impact of non-tariff measures on Moroccan foreign trade, the starting point is the famous model of gravity inspired by the law of gravitation or law of universal attraction, discovered by Isaac Newton:

$$
F_{i j}=G \frac{M_{i} M_{j}}{D_{i j}^{2}}
$$

Where: $F_{i j}$ represents the force of attraction between two elements, $M_{i}$ et $M_{j}$ represents the weights of the elements, $D_{i j}$ represents the distance separating element $\mathrm{i}$ from element $\mathrm{j}$, and finally $\mathrm{G}$ is the gravitational constant.

In physics, any two bodies attract each other in proportion to their mass and inversely proportional to the distance between their centers of gravity. The economist [21] was the first to draw inspiration from Newton's law of universal gravitation to describe the dynamics of bilateral trade. The international trade gravity equation established by Tinbergen is as follows:

$$
X_{i j}=G \frac{G D P_{i} G D P_{j}}{D_{i j}^{2}}
$$

Where the volume of trade $(\mathrm{X})$ between two countries " $\mathrm{i}$ " and " $\mathrm{j}$ " is proportional to their gross domestic product (GDP) and inversely proportional to the distance (D) between them. In other words, the larger the size of the economic partners, the more they exchange among themselves; Or the more remote they are from each other, the less important their bilateral trade.

In our study, we draw on the theoretical framework developed by [22] to derive a gravitational empirical equation explaining the impact of the determinants of trade and to assess the degree of restriction of non-tariff measures applied in Morocco's trade with its Commercial Partners. By doing a linearization work, we present the simplest formula of the economic application of the gravitational model: 


$$
\ln \text { Exportation }_{i j}=\alpha_{0}+\alpha_{1} \ln P I B_{i}+\alpha_{2} \ln P I B_{j}+\alpha_{3} \ln \text { Distance_Geo }_{i j}+\delta_{i j}
$$

Exportation $_{i j}$ : represents Morocco's exports or imports from the trading partner;

$\alpha_{0}$ : represents is a constant;

$G D P_{i}$ et $G D P_{j}$ : represents respectively the GDP of Morocco and the trading partner;

Distance_Geo $_{i j}$ : the geographical distance between Morocco and its trading partner;

$\alpha_{1}, \alpha_{2}$ et $\alpha_{3}$ : represents the effect capture parameters of the various variables;

$\delta_{i j}:$ an error term.

The integration of the Ln into the gravity equation makes it possible to reduce the power function to a linear function, and thus to apply the ordinary least squares (OLS) method in econometric processing. This form also makes it possible to interpret the coefficients as elasticities of trade flows compared with the explanatory variables.

The model of [23], a pioneer in the new theories of international trade, shows how the volume of trade a country maintains with the rest of the world is proportional to its size and negatively affected by trade barriers and distance. After our review of literature, it turns out that the integration of several variables is paramount for a better meaning of the results. Thus, the distance between two countries cannot be measured solely by its geographical dimension, and therefore we must also integrate the socio-cultural dimensions of distance.

Widely used in commercial literature, gravitational equations are recognized for their empirical success. Additional variables were introduced to improve the theoretical justification of the gravity models. The introduction of the variable on non-tariff measures enabled us to answer our basic problem.

Thus, our gravitational equation includes the explanatory variables that take into account the standard variables of the gravitational model: GDP, GDP per capita and geographical distance. We calculate:

$$
\ln S u m_{-} G D P_{i j}=\ln \left(G D P_{i}+G D P_{j}\right)
$$

Ratio $_{i j} G D P_{/ \text {capita }}$ : represents the indicator of the relative difference in factor endowments;

The ratio Ratio $_{i j} G D P_{/ \text {capita }}$ is often taken as an indicator of the difference in factor endowments, the economic gap between two exchange markets. According to [24], a larger per capita income difference would imply a greater disparity in factor endowments, which translates into a low level of intra-industry trade. The ratio $P I B_{/ H a b}$ should take a negative sign for intra-industry and positive inter-branch trade. Economic studyof [25] shows that trade between the MED countries is essentially inter-branch, confirming the predominance of the logic of comparative advantages with a very low share of real intra-trade -branch.

$$
\text { Ratio }_{i j} G D P_{/ \text {capita }}=\frac{G D P_{\text {/capita }} \text { du Maroc }}{G D P_{\text {/capita }} \text { du partenaire }}
$$

The geographical distance between Morocco (i) and its trading partner (j) is the distance between the main cities of the two trading partners, weighted by the share of each city in the total population of the country (Distance_Geo $o_{i j}$ ).

We also introduce a tariff variable marked "Tarif_NPF $F_{i j}$ " representing the Most Favored Nation (MFN) tariffs applied to products from Morocco (i) to partners (j). This variable is an obstacle to trade and is widely used to measure the costs of bilateral trade. The variable "Tarif_NPF $F_{i j}$ " is measured at each tariff line corresponding to each product category coded to SH with 6 digits. It allows us to calculate the impact of customs duties, at each tariff line, on the volume of imports of trading partners. A negative sign of this variable will support the idea of tariffs as a barrier to trade.

We integrate the non-tariff variable "NTM $M_{i j}$ ", which allows us to measure the role of non-tariff measures in the foreign trade of Morocco. It will allow us to estimate the impact of NCDs on imports from partner countries (j) from Morocco (i). The variable "NTM $M_{i j}$ " represents the sum of the number of NTMs applied to each product category coded to HS with 6 digits. The statistics used included the following categories: Anti-dumping Measures, State Trading Enterprises, Compensatory Measures, Technical Barriers to 
Trade, Quantitative Restrictions, Safeguard Measures, Sanitary and Phytosanitary Measures, Tariff Quotas, and finally Export Subsidies.

Knowing that $80 \%$ of international trade is by sea, our study is based on the commercial partner's connectivity index of regular shipping (Iindice_Connect_TMR ${ }_{j}$ ) and on the bilateral connectivity index of regular maritime transport between Morocco and the trading partner (Iindice_Connect_Bilat_TMR $R_{i j}$ ). Transport connectivity is a key determinant of bilateral exports. The UNCTAD bilateral connectivity index for regular maritime transport is expected to accurately reflect maritime connectivity between country pairs.

Thus, a relative variable marked "IPLog_Sum $i j$ ", qualified as an indicator representing the level of logistics performance in the trading partner countries of Morocco, is introduced. This variable captures the impact of logistics efficiency on trade flows.

The quantitative variable referring to "trade facilitation" is introduced to examine the steps required when importing goods from Moroccan export destination countries and thus capturing the impact of trade facilitation on development of bilateral trade flows (Trade $F_{j}$ ).

We have integrated other explanatory variables to improve the explanatory power of our gravity model while keeping the most influential variables. We decide here to add two qualitative variables, namely the common language and the colonial history, thus making it possible to refine the basic gravity model. The two qualitative variables indicating cultural proximity are represented by the common language ( Langue $_{i j}$ ) and the colonial history (Colonial_link $k_{i j}$ ). They will allow us to assess whether sharing an ethnic language or having a colonial history can positively influence bilateral trade. Thus, these two variables are introduced in our gravitational model, insofar as they are likely to reduce transaction costs.

Finally, the last quantitative variable concerns governance that represents the perceptions of governance in the countries destined for Moroccan exports, it captures the impact of institutional quality on bilateral trade (Governance_Indicators ${ }_{j}$ ). Thus, our final model is as follows:

$\ln$ Exportation $_{i j}=\alpha_{0}+\alpha_{1} \ln$ Sum_GDP $_{i j}+\alpha_{2} \ln$ Ratio $_{i j} G D P_{/ \text {capita }}+\alpha_{3} \ln$ Distance_Geo $_{i j}$

$+\alpha_{4} \ln$ Tarif_NPF $F_{i j}+\alpha_{5} N T M_{i j}+\alpha_{6} \ln$ Iindice_Connect_TMR $R_{j}$

$+\alpha_{7} \ln$ Iindice_Connect_Bilat_TMR $R_{i j}+\alpha_{8} \ln$ IPLog_Sum $_{i j}+\alpha_{9} \ln$ Trade_$F_{j}$

$+\alpha_{10}$ Langue $_{i j}+\alpha_{11}$ Colonial_link $_{i j}+\alpha_{12} \ln$ Governance_Indicators $_{j}+\delta_{i j}$

Exportation $_{i j}$ : represents exports from Morocco (i) to the trading partner (j); $\alpha_{0}$ : represents is a constant;

Sum_GDP ${ }_{i j}$ : the sum of the GDP of Morocco and the trading partner;

Ratio $_{i j} G D P_{\text {capita }}$ : represents the indicator of the relative difference factorial allocations;

Distance_Geo $_{i j}$ : the geographical distance between Morocco and its trading partner;

Tarif_NPF $F_{i j}$ : represents the Most Favoured Nation (MFN) tariff rate applied on products exported from Morocco to the trading partner;

$N T M_{i j}$ : the number of non-tariff measures applied for each category of products;

Iindice_Connect_TMR $R_{j}$ : Regular maritime transport connectivity index of the trading partner;

Iindice_Connect_Bilat_TMR $R_{i j}$ : Index of bilateral connectivity of regular maritime transport between Morocco and the trading partner.

IPLog_Sum ${ }_{i j}$ : represents the sum of the Logistics Performance Index;

Trade_ $F_{j}$ : trade partner "Trade Facilitation Index";

Langue $_{i j}$ : dichotomous variable capturing the existence or not of a common language between the two countries;

Colonial_link $_{i j}$ : dichotomous variable capturing the existence or not of a colonial link between the two countries;

Governance_Indicators $s_{j}$ : indicator capturing perceptions of the governance of the trading partner;

$\alpha_{i}$ avec $\in\{1,2,3, \ldots, 12\}$ : represents the effect capture parameters of the various variables;

$\delta_{i j}:$ an error term.

In order to analyse empirically the impact of non-tariff measures on Moroccan foreign trade, we used the equation above estimated over the period 2000-2015 for which we have data for the following countries: Austria, Belgium, Bulgaria, Cyprus, Czech Republic, Denmark, Estonia, Finland, France, Germany, Hungary, Ireland, Italy, Latvia, Lithuania, Poland, Portugal, Romania, Slovenia, Sweden, Tunisia, and Turkey. In order to 
respond to our problems, we have combined developed and developing countries in a database of 4242 tariff lines.

\subsection{Choice of estimator and method of calculating ad-valorem tariff equivalents}

The selection of the estimator is very important in the context of statistical analyses based on randomly selected samples and may lead to erroneous conclusions. We have some observationswith the absence of import flows between our two partners, removing these observations may create a selection bias. We will opt for an econometric estimator which can take into account the problem of zero flows: Heckman two-stage. The Heckman correction is a statistical approach which consists in making a maximum likelihood estimate of the "Probit" model in a first step, and in a second step in the conditional expectation using the "Mills" statistic in the original equation, and makes an Ordinary Least Squares (OLS) estimate to evaluate the effect of the explanatory variables on exports from Morocco.

After estimating the parameters of our gravitational model, we proceeded to calculate ad-valorem tariff equivalents (AVEs). Our approach consisted first of all of using our original equation to make two estimates of Moroccan exports by cancelling the effect of MFN tariffs and non-tariff measures by replacing their values by zero in our database. From the old and new values of exports, we used the elasticity method to calculate the tariff equivalent of NTMs. We have drawn inspiration from the work of [26] to transform the effect-quantity into price-impact using the elasticity of import demand.

$$
E_{\text {npf }}=\frac{\text { Tarrif }_{\text {null }}-\text { Tarrif }_{\text {Applied }}}{\text { Export }_{\text {npf_null }}-\text { Export }_{\text {Applied }}} \quad E_{\text {mnt }}=\frac{M N T_{\text {null }}-M N T_{\text {Applied }}}{\text { Export }_{\text {mnt_null }}-\text { Export }_{\text {Applied }}}
$$

$E_{n p f}:$ represents the elasticity of import demand in relation to tariffs;

$E_{m n t}:$ represents the elasticity of import demand relative to NTMs;

Export $_{\text {Applied }}$ : represents the value of exports from Morocco;

Tarrif $_{\text {null }}$ : the customs tariff assumed to be zero in the estimate;

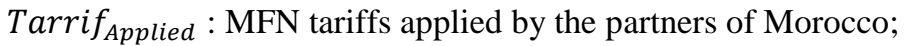

$M N T_{\text {null }}$ : non-tariff measures assumed to be zero in the estimate;

$M N T_{\text {Applied }}$ : represents the number of NTMs applied by the partners in Morocco.

Export $_{\text {npf_null }}$ : estimated exports assuming zero customs duties.

Export $_{\text {mnt_null }}$ : Estimated exports assuming a zero effect of NTMs.

We have assumed for our estimates that Tarrif $f_{\text {null }}=0$ and that $M N T_{\text {null }}=0$, and that the behaviour of importers is the same for NTMs as for tariffs and therefore $E_{n p f}=E_{m n t}$; That said the effect of the tariff and the same as non-tariff measures. After removing Tarrif $f_{\text {null }}$ and $M N T_{\text {null }}$ equations, we obtain the final equation for calculating ad-valorem tariff equivalents:

$$
M N T_{\text {Applied }}=\frac{\text { Tarrif }_{\text {Applied }} \times\left(\text { Export }_{\text {mnt_null }}-\text { Export }_{\text {Applied }}\right)}{\text { Export }_{\text {npf_null }}-\text { Export }_{\text {Applied }}}
$$

After assuming the variable $M N T_{\text {Applied }}$ as an unknown in the equation, it will become the ad-valorem tariff equivalent capture variable and represents a transformation of non-tariff measures into tariffs. The following paragraph presents the empirical results and the confirmation of the starting hypotheses.

\section{Empirical Results}

We estimated the gravitational equation that allowed us to measure the impact of the determinants of international trade on Moroccan exports to the 28 countries included in the study. The estimator used is: Heckman two-stages, and our dependent variable is: Exportation $_{i j}$ representing Morocco's exports to trading partners. 


\subsection{Estimation of equation parameters}

We are first interesting on the significance of the variable $M N T_{i j}$ and then we will interpret the results obtained from the other explanatory variables. The results of the estimation reported in the table below show that the estimated coefficient has a negative sign $(\operatorname{Reg}=-0.175, \mathrm{Z}=-34.5, \mathrm{P}$-value $=0.000)$, which proves the restrictive impact of non-tariff measures On Moroccan exports to the countries of study. Each country applies specific non-tariff measures to protect its economy. Non-tariff measures have become central to state trade policies, giving them room for manoeuvre in influencing the volume of imports and exports, especially for sensitive products. Moroccan exports are increasingly suffering from this type of obstacle disguised under the banner of protecting human, animal and environmental health [27].

The NTMs are often called "soft" barriers, but despite their name, these trade barriers are nothing soft measures. The estimated parameter for Tarif_NPF $i j$ variable also gives a negative and very significant sign $(\operatorname{Reg}=-0.049 ; \mathrm{Z}=-3.38 ; \mathrm{P}$-value $=0.001)$. This shows that non-tariff measures are more restrictive than tariffs. Thus, the Ratio ${ }_{i j} P_{I} B_{/ \text {Hab }}$ has a negative sign $(\mathrm{Reg}=-0.187, \mathrm{Z}=-1.44, \mathrm{P}$-value $=0.15)$ which may mean that trade between Morocco and the majority of the countries studied are of intra-branch type, however, this estimate presents 15\% error. In terms of GDP, the results show that when the GDP of both partners increases, bilateral trade also increases, this implies an increase in Moroccan exports $(\operatorname{Reg}=1.249, \mathrm{Z}=21.61, \mathrm{P}$-value $=0.000)$.

Another more important empirical result is that the variable Iindice_Connect_Bilat_TMR $R_{i j}$ shows that Morocco tends to exchange more with the partners with which it is connected directly by regular maritime lines $(\operatorname{Reg}=0.232, \mathrm{Z}=3.64 ; \mathrm{P}$-value $=0.000)$. This can be justified by the importance of maritime transport in international trade and not only in trade in Morocco. Also, Moroccan exports become very important when it comes to trade with countries that have at least $9 \%$ of the population who speak a common language with Morocco $(\operatorname{Reg}=1.116, \mathrm{Z}=6.87 ; \mathrm{P}$-value $=0.000)$. The colonial link seems to have a negative impact on Moroccan exports $(\operatorname{Reg}=-0.868, \mathrm{Z}=-3.18, \mathrm{P}$-value $=0.001)$, which is contradictory to the international trade literature which states that countries exchange more when they have (Trade between the country and its former colonizer or trade between countries that had the same colonizer). This incompatibility with international trade theories can be explained in part by the nature of the study sample, which mostly includes countries with which Morocco has no colonial link except France, Spain and Tunisia.

Table 1: Results of parameters estimation

\begin{tabular}{|c|c|c|c|c|c|c|}
\hline & Coef. & Std. Err. & $\mathrm{Z}$ & $\mathrm{P}>\mathrm{Z}$ & \multicolumn{2}{|c|}{ [95\% Conf.Interval] } \\
\hline Sum_GDP $P_{i j}$ & 1.249384 & .0578171 & 21.61 & 0.000 & 1.136065 & 1.362704 \\
\hline Ratio $_{i j} G D P_{/ \text {capita }}$ & -.1870679 & .1300152 & -1.44 & 0.150 & -.441893 & .0677573 \\
\hline Distance_Geo $_{i j}$ & .3474069 & .1095042 & 3.17 & 0.002 & .1327827 & .5620312 \\
\hline Tarif_NPF $F_{i j}$ & -.0490896 & .0145238 & -3.38 & 0.001 & -.0775557 & -.0206236 \\
\hline$N T M_{i j}$ & -.1758296 & .0050969 & -34.50 & 0.000 & -.1858193 & -.1658399 \\
\hline Iindice_Connect_TMR $_{j}$ & -.2863031 & .0696638 & -4.11 & 0.000 & -.4228416 & -.1497646 \\
\hline Iindice_Connect_Bilat_TMR $_{i j}$ & .2323488 & .0638417 & 3.64 & 0.000 & .1072213 & .3574763 \\
\hline IPLog_Sum $_{i j}$ & -2.623443 & .4379761 & -5.99 & 0.000 & -3.48186 & -1.765026 \\
\hline Trade_ $F_{j}$ & -.0317926 & .0331498 & -0.96 & 0.338 & -.096765 & .0331797 \\
\hline Langue $_{i j}$ & 1.116302 & .1625511 & 6.87 & 0.000 & .7977081 & 1.434897 \\
\hline Colonial_link $_{i j}$ & -.8680497 & .273266 & -3.18 & 0.001 & -1.403641 & -.3324581 \\
\hline Governance_Indicators $_{j}$ & .0015923 & .0264238 & 0.06 & 0.952 & -.0501975 & .0533821 \\
\hline _cons & -28.55801 & 1.335191 & -21.39 & 0.000 & -31.17493 & -25.94108 \\
\hline \multicolumn{7}{|l|}{ mills } \\
\hline lambda & .0702862 & .2560753 & 0.27 & 0.784 & -.4316122 & .5721845 \\
\hline rho & \multicolumn{6}{|l|}{0.02373} \\
\hline sigma & \multicolumn{6}{|l|}{2.9615869} \\
\hline \multicolumn{7}{|l|}{ Other Statistics } \\
\hline Number of obs & \multicolumn{6}{|l|}{4242} \\
\hline Wald chi2(12) & \multicolumn{6}{|l|}{1392,45} \\
\hline Prob > chi 2 & \multicolumn{6}{|l|}{0,000} \\
\hline
\end{tabular}

Source: Authors elaboration

The other variables show unsatisfactory results as they show unexpected signs and do not conform to the literature (the case of geographical distance, the regular maritime transport connectivity index and the logistics performance index) or non-significant parameters (the case of Trade Facilitation Index and the Governance Index).

The analysis of the parameter estimated to capture the impact of non-tariff measures is not sufficient to detect the extent of the restriction of these obstacles on Moroccan exports. To remedy this, we did an analysis of ad-valorem tariff equivalents. This will allow us to detect the effect through a NTM transformation into easily interpretable customs duties. The results are presented in the following paragraph. 


\subsection{Calculation of ad-valorem tariff equivalents}

In order to analyse the real impact of non-tariff measures on Moroccan foreign trade, we calculated the ad-valorem tariff equivalents using elasticities of import demand. The results show a much greater effect than the tariffs applied to Moroccan exports. The first reading of the table shows that there is a great difference between the different trading partners of Morocco. As a result, some sectors are more affected than others. We conduct an analysis by sector.

For the agriculture sector, the ad-valorem tariff equivalent is between $1.45 \%$ and $97.59 \%$. Countries heading the partners that hinder Moroccan agricultural exports are Jordan (16,60\%), Slovenia $(18,36 \%)$, the Netherlands (21,90\%), Hungary (36,90\%), Romania (37.79\%), Turkey (61.65\%) Egypt (95.25\%) and Poland (97.59\%). However, countries that apply low restrictive non-tariff measures for agricultural exports are Portugal $(1.45 \%)$, Tunisia (1.45\%), Denmark (1.45\%), Italy (2.87\%), Spain (3.30\%), Austria (3.93\%). Tunisia is the only developing country that is on the list of countries that hamper the Moroccan agricultural exports.

The analysis of the restriction of the industrial sector gives us similar results to the agricultural sector. The calculated ad-valorem tariff equivalent is $0.28 \%$ and $74.09 \%$, so that there are too many differences between countries in terms of restriction. At the head of the countries that hinder most Moroccan industrial exports, we find: Egypt (13.77\%), Slovenia (17.87\%), Romania (36.11\%), France (44.33\%), Jordan (56.05\%), and Turkey (74.09\%). Three developing countries show themselves as very restrictive countries towards Moroccan industrial products. However, no developing country is among countries that are not restricted to Moroccan exports. Non-tariff measures for countries such as Spain $(0,28 \%)$, Belgium $(0,47 \%)$, Italy $(0,85 \%)$, the Netherlands $(0,87 \%)$, Portugal $(1,06 \%)$, The United Kingdom (1.24\%), Austria (1.54\%), Cyprus (2.36\%) and Germany (2.58\%) are less restrictive to Moroccan industrial exports.

Moroccan exports of the mineral sector seem to suffer to a lesser degree than other types of product. Their ad valorem tariff equivalents are between $0 \%$ and $40.65 \%$. The results spread that Spain $(0.00 \%)$, Belgium $(0.00 \%)$, the UK $(0.00 \%)$, Austria $(0.00 \%)$, Ireland $(0.00 \%)$, Bulgaria $(0.00 \%)$, and Egypt $(0.00 \%)$ have no restrictions on exports from the Moroccan mineral sector. While Slovenia (40.65\%), Turkey (22.13\%), Romania $(13.95 \%)$, Finland $(13.63 \%)$, Tunisia $(13.49 \%)$, Germany $(12.45 \%)$, and Lithuania $(9.60 \%)$ are countries that hinders most Moroccan exports mineral products.

Table 2: Ad-valorem tariff equivalents by country and by sector

\begin{tabular}{|c|c|c|c|c|}
\hline Countries & Agriculture & Industrial products & Mineral products & Average AVE \\
\hline Germany & $8,139 \%$ & $2,576 \%$ & $12,454 \%$ & $7,723 \%$ \\
\hline Austria & $3,931 \%$ & $1,541 \%$ & $0,000 \%$ & $1,824 \%$ \\
\hline Belgium & $6,888 \%$ & $0,467 \%$ & $0,000 \%$ & $2,452 \%$ \\
\hline Bulgaria & $10,175 \%$ & $6,745 \%$ & $0,000 \%$ & $5,640 \%$ \\
\hline Cyprus & $6,516 \%$ & $2,356 \%$ & $1,724 \%$ & $3,532 \%$ \\
\hline Croatia & $12,824 \%$ & $5,387 \%$ & $2,567 \%$ & $6,926 \%$ \\
\hline Denmark & $1,455 \%$ & $5,564 \%$ & $9,440 \%$ & $5,486 \%$ \\
\hline Egypt & $95,253 \%$ & $13,766 \%$ & $0,000 \%$ & $36,339 \%$ \\
\hline Spain & $3,297 \%$ & $0,278 \%$ & $0,000 \%$ & $1,192 \%$ \\
\hline Estonia & $7,814 \%$ & $4,056 \%$ & $1,119 \%$ & $4,330 \%$ \\
\hline Finland & $7,639 \%$ & $9,902 \%$ & $13,631 \%$ & $10,390 \%$ \\
\hline France & $5,958 \%$ & $44,335 \%$ & $6,603 \%$ & $18,965 \%$ \\
\hline Hungary & $36,902 \%$ & $7,564 \%$ & $7,150 \%$ & $17,205 \%$ \\
\hline Irland & $8,118 \%$ & $2,676 \%$ & $0,000 \%$ & $3,598 \%$ \\
\hline Italy & $2,870 \%$ & $0,849 \%$ & $2,213 \%$ & $1,977 \%$ \\
\hline Jordan & $16,604 \%$ & $56,047 \%$ & $7,308 \%$ & $26,653 \%$ \\
\hline Latvia & $11,587 \%$ & $6,357 \%$ & $3,593 \%$ & $7,179 \%$ \\
\hline Lithuania & $11,849 \%$ & $5,860 \%$ & $9,601 \%$ & $9,103 \%$ \\
\hline Netherlands & $21,896 \%$ & $0,871 \%$ & $1,377 \%$ & $8,048 \%$ \\
\hline Poland & $97,587 \%$ & $5,061 \%$ & $2,396 \%$ & $35,015 \%$ \\
\hline Portugal & $1,449 \%$ & $1,057 \%$ & $2,814 \%$ & $1,773 \%$ \\
\hline Czech Republic & $15,451 \%$ & $8,889 \%$ & $8,807 \%$ & $11,049 \%$ \\
\hline Romania & $37,794 \%$ & $36,109 \%$ & $13,952 \%$ & $29,285 \%$ \\
\hline UK & $4,772 \%$ & $1,236 \%$ & $0,000 \%$ & $2,003 \%$ \\
\hline Slovenia & $18,360 \%$ & $17,872 \%$ & $40,648 \%$ & $25,626 \%$ \\
\hline Sweden & $7,662 \%$ & $3,122 \%$ & $7,088 \%$ & $5,957 \%$ \\
\hline Tunisia & $1,450 \%$ & $5,682 \%$ & $13,494 \%$ & $6,875 \%$ \\
\hline Turkey & $61,645 \%$ & $74,095 \%$ & $22,130 \%$ & $52,623 \%$ \\
\hline Average AVE & $27,131 \%$ & $19,071 \%$ & $9,723 \%$ & $18,641 \%$ \\
\hline
\end{tabular}

Source: Authors elaboration

The calculation of ad-valorem tariff equivalents shows that non-tariff measures are more restrictive in Morocco-South trade than in South-North trade. The majority of developing countries found themselves at the top of the list of countries more restrictive to Moroccan exports. This result is confirmed by the calculation of 
the average of the ad-valorem equivalents for the three agreements included in the studies. Exports under the Agadir Agreement (25.63\%) and under the Morocco-Turkey Agreement (52.62\%) are much more affected by non-tariff measures than the Morocco-European Union agreement.The results by sector of exports under each agreement show similar results. Exports of products from all sectors within the European Union are less hampered by non-tariff measures than those exported to Turkey or the countries of the Agadir Agreement, with the exception of mineral products for which the Agadir agreement has the lowest tariff equivalent for the study $(5.99 \%)$.

Table 3: Ad-valorem tariff equivalents by agreement and by sector

\begin{tabular}{|l|l|l|l|l|}
\hline Agreement & Agriculture & Industrial products & Mineral products & Average AVE \\
\hline Agadir Agreement & $42,957 \%$ & $27,948 \%$ & $5,996 \%$ & $25,634 \%$ \\
\hline Morocco-Turkey & $61,645 \%$ & $74,094 \%$ & $22,130 \%$ & $52,623 \%$ \\
\hline Morocco-EU & $17,623 \%$ & $9,279 \%$ & $9,394 \%$ & $12,099 \%$ \\
\hline Average AVE & $27,130 \%$ & $19,070 \%$ & $9,722 \%$ & $18,641 \%$ \\
\hline
\end{tabular}

Source: Authors elaboration

Making an analysis by sector, it appears that the sector of agriculture is the sector most affected by restrictive non-tariff measures given its calculated ad-valorem tariff equivalent $(27.13 \%)$. In second place are exports of industrial products with a tariff equivalent which amounts to 19.07\%. Finally, exports of mineral products are less constrained by non-tariff barriers and have an ad valorem equivalent of only $9.72 \%$.

The results obtained confirm some initial assumptions and refute other hypotheses. The following section attempts to detail and discuss these results in order to try to find explanations to the reason for the rejection of certain assumptions.

\section{Discussion of findings and conclusions}

Non-tariff measures are an important source of barriers to Moroccan foreign trade and are also a particular challenge for exporters. These measures are generally implemented for the sake of protecting economies, and they often have a negative effect on trading volume. Unlike tariffs, diversity and complexity of non-tariff measures make the overall assessment of their negative effects an extremely complex task. The removal of tariff barriers in the markets of countries with which Morocco has signed free trade agreements has been accompanied by a massive increase in non-tariff barriers.

According to the results of our econometric estimation, non-tariff measures appear to have a negative effect on Moroccan foreign trade. This shows the restrictive impact of NTMs on the development of Moroccan exports, through the multiplicity of technical standards, cumbersome customs and administrative procedures and quantitative restrictions. We also saw a difference in impact on the various sectors confirming the hypothesis according to which Moroccan exports suffer from restrictive MNT applied by the commercial partners of Morocco, limiting the volume of exports differently according to sectors. Moreover, we have asked ourselves the question of the viability of the degree of restriction according to the level of development of each country. Thus, we assumed that developed countries benefit from their technological advance to impose restrictive standards and that trade Morocco-developed countries suffers from more restrictive MNTs than those applied in Morocco-Developing country trade.

The results of the calculation of the ad-valorem tariff equivalents show that the developing countries have a very high level of protection due to NTMs in relation to the developed countries. The Agadir Agreement countries and Turkey apply a relatively high level of protection, namely $6.87 \%$ for Tunisia, $26.65 \%$ for Jordan, $36.33 \%$ for Egypt, and 52, 62\% for Turkey. On the other hand, the level of protection displayed by the countries of the Morocco-European Union agreement amounts to $12.09 \%$. Only Tunisia has noticed a low level of protection among the developing countries integrated in the study. Some countries of the European Union have a very low level of protection, not exceeding 3\% such as the United Kingdom and Belgium, and less than $2 \%$ as in Spain, Portugal, Austria and Italy. These results lead us to reject the hypotheses saying that developed countries benefit from economic progress to impose restrictive NTMs. We conclude that barriers applied by the developing countries are much more restrictive than those imposed by developed countries. To remedy this situation, and in order to allow Morocco to benefit fully from the advantages offered by the free trade agreements, the country has an interest in implementing a more effective trade policy. A policy based on the promotion and simplification of export operations as well as on accompanying measures to exporters, especially for the sectors most affected. Morocco's alignment with international standards of agricultural products, especially European and American, characterized by their rigor, would allow Moroccan exporting companies to have easy access to foreign markets.

We notice that beyond the analysis and the significant results of our empirical work, our paper has a number of limitations. The major handicap of our work stems from our econometric approach to trade in a limited number of developing countries. Other empirical work has used an approach on a large sample of 
countries. We justify this choice by the difficulty of obtaining data over several years for the developing countries. It should be noted that extensions of NTMs databases can only be carried out by international organizations because of the colossal work involved.

\section{References}

[1] WTO. (2012). Rapport sur le commerce mondial 2012 - Commerce et politiques publiques : gros plan sur les mesures non tarifaires au XXIe siècle

[2] OCDE. (2005). Analyse des obstacles non tarifaires touchant les pays en développement. Editions OCDE, (16)

[3] Baldwin, R, (1970), « Non-Tariff Distortions in International Trade », Washington, DC: Brookings Institution

[4] Carrere, C., \& Melo De, J. (2009). Non-Tariff Measures: What do we Know, What Should be Done? Halshs-00553599, 2009-33, (2009.33)

[5] WTO. (2012). Rapport sur le commerce mondial 2012 - Commerce et politiques publiques : gros plan sur les mesures non tarifaires au XXIe siècle

[6] Maertens, M., \& Swinnen, J. F. M. (2009). Trade, Standards and Poverty: Evidence from Senegal. Centre for Institutions and Economic Performance Katholieke Universiteit Leuven Belgium, (October), 1-41

[7] Moenius, J. (2006), « Do National Standards Hinder or Promote Trade in Electrical Products », IEC Centenary Challenge Papers, Commission Électrotechnique Internationale, Genève

[8] Melitz, M. J. (2005). When and how should infant industries be protected? Journal of International Economics, 66(1), 177-196. https://doi.org/10.1016/j.jinteco.2004.07.001

[9] CNUCED. (2005). Obstacles Non Tarifaires : Méthodes, classifications, quantification et incidences sur le développement. Note Du Secrétariat de La CNUCED, 51902, 1-31

[10] Kee H.L., Nicita, A. \& Ollarreaga, M. (2009), «Estimating Trade restrictiveness indices », The Economic Journal, 119: 172-199

[11] Hoekman, B. \& Nicita, A. (2011), « Trade Policy, Trade Costs, and Developing Country Trade », World Development 39(12): 2069-2079

[12] WTO. (2012). Rapport sur le commerce mondial 2012 - Commerce et politiques publiques : gros plan sur les mesures non tarifaires au XXIe siècle

[13] Henn, C., \& Mcdonald, B. (2011). Protectionist Responses to the Crisis: Damage Observed in Product-Level Trade. IMF Working Paper, WP/11/139

[14] Hoekman, B. \& Nicita, A. (2008), « Trade policy, trade costs, and developing country trade », World Bank Policy Research WP \#4797

[15] CNUCED. (2005). Obstacles Non Tarifaires : Méthodes, classifications, quantification et incidences sur le développement. Note Du Secrétariat de La CNUCED, 51902, 1-31

[16] CNUCED. (2012). Classification of Non-Tariff Measures. United Nations Publication UNCTAD/DITC/TAB/2012/2, (February 2012)

[17] Disdier, A.-C., Fontagné, L., \& Momouni, M. (2008). The impact of regulations on agricultural trade: Evidence from the SPS and TBT agreements. American Journal of Agricultural Economics, 90(2), 336-350

[18] Disdier, A.-C., Fekadu, B., Murillo, C., \& Wong, S. A. (2008). Trade Effects of SPS and TBT Measures on Tropical and Diversification Products. Economic Policy, 12, 140. https://doi.org/10.7215/AG_IP_20080501A T5 - ICTSD Project on Tropical Products M4 - Citavi

[19] Chen, M.X., Otsuki, T. \& Wilson, J.S. (2006), « Do Standards Matter for Export Success? », Policy Research Working Paper 3809, Banque Mondiale, Washington (D.C.)

[20] Djankov, S., Freund, C. \& Pham, C.S. (2010), « Trading on Time », Review of Economics and Statistics, Vol. 92, No. 1, pp. 166173

[21] Tinbergen, J. (1962). An analysis of world trade flows. Shaping the world economy, 1-117

[22] Anderson, J. \& van Wincoop, E. (2004), «Trade Costs», Journal of Economic Literature, American Economic Association, vol.42(3), pages. 691-75, September 2004

[23] Krugman, Paul (1980), « Scale economies, product differentiation, and the patterns of trade », in American Economic Review, vol. $70, \mathrm{n}^{\circ} 5$

[24] Helpman, E. \& Krugman, P. (1985), «Market Structure and Foreign Trade: Increasing Returns, Imperfect Competition and the International Economy», Cambridge, Mass.: MIT Press.

[25] Péridy, N. (2004), « L'Impact de la Politique Euro-méditerranéenne sur les Echanges UE-Maroc : Application d'un Indicateur de Performance à l'Exportation ", Région et Développement, Numéro 19, pp.55-82

[26] Kee H.L., Nicita, A. \& Ollarreaga, M. (2009), « Estimating Trade restrictiveness indices », The Economic Journal, 119: 172-199

[27] Cen+B1:B27tre du Commerce International (ITC). (2012). Maroc: Perspectives des entreprises. Série ITC Sur Les Mesures Non Tarifaires, (Document technique) 